\title{
Teachers' Approaches to Classroom Assessment: A Large-scale Survey
}

Christopher DeLuca ${ }^{a}$, Adelina Valiquette ${ }^{a}$, Andrew Coombs ${ }^{a}$, Danielle LaPointe-McEwana ${ }^{a}$, \& Ulemu Luhanga ${ }^{b}$

aFaculty of Education, Queen's University, Kingston, Canada

bSchool of Medicine, Emory University, Atlanta, United States

Full Citation:

Christopher DeLuca, Adelina Valiquette, Andrew Coombs, Danielle LaPointe-McEwan \& Ulemu Luhanga (2018)Teachers' approaches to classroom assessment: a large-scale survey, Assessment in Education: Principles, Policy \& Practice, 25:4, $355-$

375. DOI: 10.1080/0969594X.2016.1244514

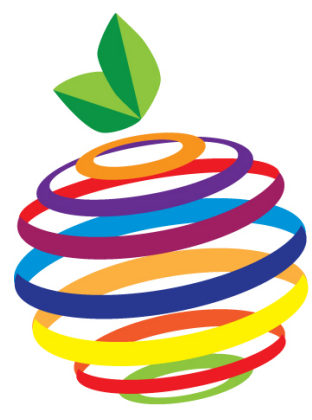

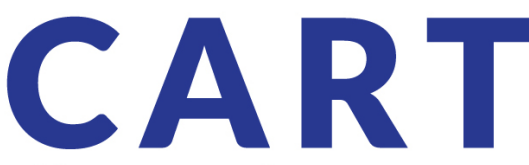

Classroom Assessment Research Team cdeluca.com

\section{Contact:}

Christopher DeLuca cdeluca@queensu.ca

@ChrisDeLuca20 


\begin{abstract}
Classroom assessment has become a cornerstone of today's standards-based system of education. However, recent policy developments, professional standards, and variable assessment education have led to significant variability in teachers' approaches to assessment. The primary purpose of this research was to use a new instrument predicated on recently published classroom assessment standards - the Approaches to Classroom Assessment Inventory - to measure teachers' (a) approaches to assessment, (b) perceived skill in current assessment tasks and responsibilities, and (c) professional learning preferences and priorities. Based on 404 teachers from across North America, this study contributes initial evidence of how teachers approach classroom assessment with respect to four dimensions: Assessment Purposes, Assessment Processes, Assessment Fairness, and Measurement Theory. Results from this study point to significant differences based on career stage and previous assessment education. The study concludes with four key implications for assessment research and practice.
\end{abstract}

Keywords: classroom assessment, assessment literacy, standards for classroom assessment, approaches to classroom assessment, assessment education, professional learning 
Classroom assessment has become a cornerstone in today's standards-based systems of education (Brookhart, 2011; Popham, 2013; Stobart, 2008). Recent policy developments throughout the United States, Canada, Europe, and elsewhere, have emphasized classroom teachers' continuous integration of student assessments throughout instruction to support student learning (Birenbaum et al., 2015; DeLuca, 2012; Popham, 2004, 2013). These policies are predicated on research arguing the benefits of assessment-based teaching on student achievement (Black \& Wiliam, 1998; Gardner, 2006; Taras, 2007), metacognitive abilities (Earl, 2003), motivation and positive self-perception (Harlen, 2006), and enhanced teacher instruction (Harrison, 2005; Lee \& Wiliam, 2005; Willis, 2010).

Given these emerging benefits and coupled with the foregoing policy developments, there has been increased attention on supporting teachers' assessment literacy — teachers' ability to negotiate and articulate classroom and cultural contexts in order to initiate, develop, practice, integrate, and use appropriate assessment approaches to promote student learning towards educational standards (Willis, Adie, \& Klenowski, 2013). However, despite repeated calls for enhanced teacher assessment literacy (Popham, 2013), research has continually demonstrated that teachers face significant challenges integrating new approaches to assessment that align with contemporary mandates and assessment theories (Bennett, 2011; DeLuca \& Klinger, 2010; MacLellan, 2004). As a result, teachers maintain variable understandings about educational assessment leading to fundamentally different orientations and classroom practices. Researchers have also noted that there is comparatively little reliable data on teachers' current approaches to assessment in relation to existing accountability demands due to a lack of contemporary assessment literacy measures (DeLuca, LaPointe-McEwen, \& Luhanga, 2016; Gotch \& French, 2014). 
The majority of quantitative research conducted on teachers' approaches to assessment has used assessment literacy measures predicated on professional standards from the early 1990s (i.e., Standard for Teacher Competency in Educational Assessment of Students, AFT, NCME \& NEA, 1990) (DeLuca et al., 2016; Gotch \& French, 2014). While these standards have significantly and positively shaped assessment research, they were developed prior to the accountability and standards-based movement and therefore do not fully measure teachers' approaches to assessment in relation to the current context of classroom assessment (Brookhart, 2011; DeLuca et al., 2016; Gotch \& French, 2014). Specifically, Brookhart (2011) noted that the 1990 Standards (AFT, NCME \& NEA, 1990) have become dated in two notable ways: (a) they do not consider current conceptions of formative assessment (i.e., assessment for and as learning), and (b) they do not consider the social issues and diverse contexts teachers face in constructing and using assessments within standards-based educational reforms. The recently published Classroom Assessment Standards (Joint Committee on Standards for Educational Evaluation, JCSEE, 2015) addresses these critiques by articulating a new set of research-based principles and guidelines for assessing student learning in relation to the current landscape of educational assessment.

The development of the new standards (JCSEE, 2015) coupled with evolving demands in classroom assessment suggests that previous assessment literacy measures may not yield strong validity in relation to current teaching contexts (DeLuca et al., 2016; Gotch \& French, 2014). Hence, the purpose of this paper was to use a new assessment literacy measure (predicated on the Classroom Assessment Standards) to analyze teachers' current approaches to classroom assessment. In particular, this research aimed to analyze classroom teachers' differential responses to contemporary assessment scenarios and explore their perceived skill related to specific assessment responsibilities relevant to accountability and standards-based frameworks of education. This research was guided by the following specific questions: 
1. How do teachers' approaches to assessment differ based on career stage, teaching division, and previous assessment education?

2. How do teachers' perceived skills in assessment tasks and responsibilities differ based on career stage, teaching division, and previous assessment education?

3. How do teachers prioritize their professional learning needs in assessment based on career stage, teaching division, and previous assessment education?

\section{Teachers' Approaches to Classroom Assessment}

Teachers' approaches to assessment are shaped by several factors including their previous experiences with assessment (as students and teachers), their values and beliefs on what constitutes valid and useful evidence of student learning, their knowledge of assessment theory, and the prevalence of systemic assessment policies (Harrison, 2005; Popham, 2013).

Additionally, various purposes of classroom assessment have been articulated differently across typologies (e.g., diagnostic-formative-summative; assessment for, of, and as learning; improvement of teaching and learning, school accountability, and student accountability) often with inconsistency (Bennett, 2011; Newton, 2007; Swaffield, 2011). In relation to this inconsistency, Newton (2007, p. 151) critically notes, "the confusion that it has engendered has not been benign and, to some extent, has actually hindered the development of sound assessment practice." Accordingly, these factors along with variable conceptions on the purposes and processes of classroom assessments has resulted in a variety of assessment approaches currently in operation within classrooms to measure and support student learning.

As recognized by Shepard (2000) in her landmark article, Assessment in a Learning Culture, classroom assessments have been historically shaped by different educational paradigms. Specifically, she argued that traditional paradigms of social efficiency curricula coupled with behaviorist learning theories favoured scientific forms of measurement resulting in 
a highly summative testing culture within classrooms. In contrast, the later emerging, social constructivist paradigm, made provisions for social constructions of knowledge and the integration of formative orientations to assessment. Her argument acknowledged that previous paradigms continue to shape the actions of teachers today, yielding diverse approaches, diverse historical views, and diverse beliefs about the intersection of teaching, learning, and assessment. As a result, the range of assessment practices in schools today spans from traditional test-based behavioristic approaches to contemporary socio-constructivist assessment practices. Classroom assessment involves all aspects of designing, administering, and utilizing assessments to support or report on student learning. Within contemporary understandings, classroom assessment has focused on diagnostic, summative (assessment of learning), and formative (assessment for and as learning) purposes and has extended to actively include learners in the assessment process.

In a recent study that examined 15 historical and contemporary standards documents related to teachers' assessment practices, temporal and geographic shifts in standards for classroom assessment were observed (DeLuca et al., 2016). Trends generally followed those articulated by Shepard (2000) with early emphasis placed on summative assessment design and classical measurement theories, and current standards emphasizing formative orientations to assessment that favor student-centered teaching and feedback. Their review further signaled shifts in how measurement theory has been conceptualized for large-scale psychometric uses and classroom teaching and learning contexts. This trend has been articulated by others (Brookhart, 2003; Moss, 2003; Parkes, 2007) who have worked to appropriate measurement concepts for use within classroom settings recognizing that some traditional conceptualizations of validity, reliability, and fairness might not work well for teachers and students. Nonetheless, traditional thinking related to these principles continues to operate and drive classroom assessment practices for some teachers. Others have adopted more contemporary classroom-based theories to 
rationalize their assessment decisions.

Studies of both pre- and in-service teachers have explored how teachers can shift their approaches to assessment from traditional to contemporary conceptions through assessment education and professional experience. Across multiple studies, it is widely acknowledged that pre-service teachers typically enter teacher education programs with summative conceptions of assessment, based largely on their experiences with assessment as a student (Cowan, 2009; DeLuca \& Klinger, 2010; Mertler, 2004, 2009; Volante \& Fazio, 2007). Consequently, preservice education courses provide critical opportunities for beginning teachers to develop knowledge and confidence in foundational assessment theory and practice and begin to shift their approaches to reflect more contemporary conceptions of assessment (DeLuca \& Bellara, 2013; MacLellan, 2004; Volante \& Fazio, 2007).

In a study of pre-service teachers' development of formative approaches to assessment throughout a four-year initial teacher education program, Cowan (2009) found that formal assessment courses, coupled with classroom practicum placements, supported pre-service teachers' development of formative approaches to assessment. However, at the end of the preservice program, these teachers were primarily implementing straightforward formative assessment practices (e.g., sharing learning goals and success criteria, using questioning) and rarely implementing more complex formative assessment practices (e.g., self- and peerassessment, providing feedback to students). In a related study, Smith, Hill, Cowie, \& Gilmore (2014) compared the assessment beliefs of first and third year pre-service teachers across four teacher education programs. Their findings showed that pre-service teachers' beliefs shifted from primarily summative to more formative conceptualizations by the end of the program. In particular, pre-service teachers became more aware of the role of students in the assessment process (i.e., assessment informs both teaching and learning) and began to negotiate the 
challenges associated with contemporary approaches to assessment within accountability-driven frameworks. These studies suggest that teacher candidates can begin to extend their conception of classroom assessment beyond strictly a summative orientation to include formative practices. As current classroom assessment demands include the use of formative, summative, and diagnostic elements, developing teachers' comprehensive understandings across these elements is critical.

Researchers have also emphasized that in-service teachers need continued support in their professional learning — both informally through classroom implementation and experimentation, and through formal professional learning structures - in order to acquire and maintain contemporary perspectives towards assessment (Lee \& Wiliam, 2005; Mertler, 2004, 2009). Several studies have examined how various models for in-service teacher professional learning have shaped teachers' approaches to assessment. These models have included assigning mentor teachers (Feeney-Jonson, 2008), collaborative inquiry and expert support (Harrison, 2005; Wiliam, Lee, Harrison \& Black, 2004), and instructional rounds (DeLuca, Klinger, Pyper, Shulha, \& Woods, 2015). Across these studies, there is increasing evidence in support of a sustained, collaborative, classroom-embedded professional learning model that engages teachers and administrators in learning about target areas of classroom assessment.

Furthermore, in a study of teachers' approaches to classroom assessment, Brown and Remesal (2012) noted fundamental differences between pre- and in-service conceptions of assessment. In particular, pre-service teachers viewed evaluation against educational standards as a support to students' learning, while in-service teachers related evaluation against educational standards to accountability mandates. In addition, pre-service teachers viewed validity issues in assessment as related to accountability mandates, while in-service teachers recognized that validity supports student learning. This study highlights the importance of: (a) studying teachers' 
approaches to assessment in both pre- and in-service contexts, and (b) attention to alignment between contemporary conceptions of and approaches to assessment across pre- and in-service contexts in order to provide meaningful and effective assessment education opportunities that develop teachers' assessment literacy throughout their careers.

\section{Measuring Teachers' Approaches to Assessment}

Researchers have developed and used a variety of instruments to measure teachers' approaches to assessment (or teachers' assessment literacy) over the past several decades. The majority of these studies have used quantitative measures founded on the 1990 Standards for Teacher Competency in Educational Assessment of Students (AFT, NCME \& NEA, 1990) (DeLuca et al., 2016; Gotch \& French, 2014). In their seminal study, Plake, Impara, and Fager (1993) examined the assessment competency of 555 teachers and 268 administrators across 45 states in the US. In the first part of their study, a 35-item instrument, the Teacher Competencies Assessment Questionnaire (TCAQ), was developed to measure the seven competency standards. Teachers' knowledge of each standard was measured through five multiple-choice items in which there were correct answers. The instrument was reviewed by a 10 -member panel from the National Council on Measurement in Education (NCME) in order to establish construct validity before being pilot-tested with 70 teachers to establish reliability estimates. As the first study to explore teacher assessment literacy, results pointed to significant gaps in teachers' understanding and use of assessments as evidenced by an average score of $66 \%$ across the 35 items. Specifically, participants lacked competency in interpreting, integrating, and communicating assessment results.

Plake et al.'s (1993) TCAQ became the basis for several subsequent studies that aimed to measure pre-service and in-service teachers' assessment literacy (O’Sullivan \& Johnson, 1993; Campbell, Murphy, \& Holt, 2002; Mertler, 2003). These studies not only pointed to the 
consistent finding that teachers lacked critical aspects of assessment literacy, but also served to provide additional reliability and validity evidence for the TCAQ. In 2004, Mertler and Campbell reconceptualized the TCAQ into the Assessment Literacy Inventory (ALI; Mertler \& Campbell, 2004, 2005) in order to situate items within classroom assessment scenarios to reflect a more practical understanding of assessment literacy. The ALI included seven scenarios, each linked to one of the Standards, with a series of five multiple-choice questions. Like O'Sullivan and Johnson (1993), Mertler and Campbell (2004, 2005) administered the ALI to students enrolled in a measurement course to determine the extent of their learning in relation to the 1990 Standards.

While the 1990 Standards have been highly useful and influential in measures of teacher assessment literacy, Brookhart (2011) articulated that the Standards have now become dated and do not fully address the formative and accountability functions of assessment especially in highly diverse educational contexts. In a recent systematic review, Gotch and French (2014) cautioned that measures predicated on these Standards no longer fully address the competencies, abilities, and expectations for teachers' assessment literacy and argued that "the psychometric evidence available to support assessment literacy measures is weak" (Gotch \& French, 2014, p. 16). Accordingly, recent research on teachers' orientations towards assessment has not been based on the 1990 Standards. For example, the work of Brown and colleagues (Brown, 2004; Brown, Hui, Yu, \& Kennedy, 2011; Harris \& Brown, 2009; Hirschfeld \& Brown, 2009) used his Teachers' Conceptions of Assessment (COA) survey to identify four constructs related to the purposes of assessment: (a) improvement of teaching and learning, (b) school accountability, (c) student accountability, and (d) treating assessment as irrelevant. The COA asks teachers to agree or disagree with various assessment purpose statements. While the clustering of statements and resulting constructs have shifted between teacher populations (e.g., pre-service versus in-service; 
Remesal \& Brown, 2012), these studies consistently demonstrate that teachers conceptualize and value assessment purposes differently pointing to potential variability in teachers' approaches to assessment.

In an effort to extend research beyond how teachers conceptualize the purposes of educational assessment and to begin to analyze their approaches to classroom assessment, we have developed and administered the Approaches to Classroom Assessment Inventory (ACAI). The ACAI is predicated on the newly published Classroom Assessment Standards (Joint Committee on Standards for Educational Evaluation, 2015), which provide a more contemporary alternative to the 1990 Standards and more accurately reflect teachers' assessment demands within accountability-driven educational systems. Building upon our previous work (DeLuca et al., 2016; Author), the ACAI enables a more nuanced measure of teachers' approaches to assessment that accounts for their orientation along four assessment literacy themes: (a) Assessment Purposes, (b) Assessment Processes, (c) Assessment Fairness, and (d) Measurement Theory. Data on teachers' approaches to assessment is coupled with their perceived skill in a series of assessment tasks and responsibilities (as based on the Classroom Assessment Standards) to provide a composite picture of teachers' approaches and perceived skill in classroom assessment. In this paper, we present the results of our administration of the ACAI to over 400 teachers with the aim of analyzing teachers' differential approaches to classroom assessment as linked to contemporary assessment standards.

\section{Method}

A survey method was used in this research to analyze classroom teachers' current approaches to classroom assessment. In particular, 404 teachers completed the ACAI survey reflecting diverse demographic groupings (i.e., career stage, teaching division, and previous assessment education). 


\section{Sample and Recruitment}

The initial sample consisted of 693 teachers with 404 teachers completing the entire survey. The sample included teachers from select regions across Canada and the United States. Participants were invited to complete the ACAI through email and list-serve invitations. Specifically, teachers were targeted through professional associations and groups including social and web media sites. Participants in the final sample included $83.9 \%$ females and $16.1 \%$ males with $35.7 \%$ between the ages of 20 and $25,36.5 \%$ between 26 and 35 , and $27.8 \%$ over 36 years old. The majority of participants worked in public (66.3\%) or publically-funded Catholic (13.6\%) schools, with $20.1 \%$ working in Independent K-12 school contexts. The majority of participants (63.6\%) had between 0-4 years of experience with 17.8\% having between 5-10 years of experience, and $18.6 \%$ having over ten years of experience. Participants were well represented from both the Primary/Junior grades Kindergarten to 6 (54.4\%) and Intermediate/Senior grades 7-12 (45.5\%) teaching divisions. Most participants (79\%) had taken at least one previous course in assessment, either in their initial teacher education or subsequently. See Table 1 for complete sample demographics.

[Insert Table 1 Here]

\section{Instrument}

The ACAI was developed on the new Classroom Assessment Standards (JCSEE, 2015) through an expert panel method and pilot testing process (for additional information of development process see Author, in press). The ACAI was composed of three parts that targeted different aspects of teachers' approaches to assessment through closed-ended questions. Part One contained 20 items (i.e., five scenarios with four items for each scenario) corresponding to each of the four assessment literacy themes (i.e., Assessment Purposes, Assessment Processes, Assessment Fairness, and Measurement Theory). For each item, teachers were asked to choose 
from three viable response options based on their individual priorities and approaches to assessment (see Table 2 for response options based on different approaches in relation to each assessment theme). Part One of the instrument generated a profile for each individual teacher, which was composed of their responses to the scenarios. Specifically, teachers' theme-based responses to the scenarios were averaged across the approaches (see Table 2) to determine their unique approach within each assessment theme.

[Insert Table 2 Here]

Part Two of the ACAI addressed teachers' perceived skill in classroom assessment through 26 items related to assessment tasks and responsibilities connected to the Classroom Assessment Standards (JCSEE, 2015). In Part Two, teachers were asked to self-assess their perceived skill related to each task/responsibility on a five-point scale ( 1 =novice, $2=$ beginner, $3=$ proficient, $4=$ competent, and 5=expert).

Part Three of the ACAI contained 26 items designed to identify teachers' priorities and preferences for assessment learning. First, teachers were asked to prioritize their interest in learning about various topics related to classroom assessment based on the Classroom Assessment Standards (JCSEE, 2015) using a five-point scale (1=very low interest; 5=very high interest). Teachers were then asked to indicate their preferred modes for professional learning in assessment using a five-point scale ( $1=$ not preferred; $5=$ highly preferred). In total, teachers were presented with 12 different modes for professional learning ranging from face-to-face full-length courses in assessment to embedded collaborative professional inquiry models to short web-based modules in assessment. The ACAI survey concluded with a set of items to collect demographic data. 


\section{Data Analysis}

For Part One of the ACAI (i.e., Approaches to Classroom Assessment scenarios), frequencies were calculated for the following three demographic variables: (a) career stage, (b) teaching division, and (c) previous assessment education. Pearson's chi-square tests were then conducted to determine if there were any significant associations between the demographic variables and approaches to assessment in relation to the four assessment literacy themes (i.e., Assessment Purposes, Assessment Processes, Assessment Fairness, and Measurement Theory).

For Parts Two and Three (i.e., Perceived Skill in Classroom Assessment, and Professional Learning Priorities and Preferences), means and standard deviations were calculated for the same three demographic variables (i.e., career stage, teaching division, and previous assessment education). Exploratory factor analyses were also conducted for Part Two and Three of the ACAI. Given that Part Two and Three were connected to the Classroom Assessment Standards (JCSEE, 2015), we were interested in examining the underlying factors that emerged and their relationship to the Classroom Assessment Standards. Principal axis factoring with oblique rotation (promax) was used to examine underlying factors (Tabachnick \& Fiddell, 2007). An oblique rotation was selected because it was expected that topics related to classroom assessment would be correlated. The Kaiser-Meyer-Olkin (KMO) measure was used to verify the sampling adequacy for the analyses. In order to determine the number of factors to retain, the eigenvalue $>$ 1 rule and the scree test were used. With the scree test, the point where the slope of the curve leveled off was used as an initial indication of the potential number of factors. From there, our aim was to find the smallest number of interpretable factors that explained the maximum amount common variability in the data. In pursuit of a simple structure, items with double loadings and/or factor loadings below .4 were removed. Factor loadings below .4 were removed because they were considered not to represent substantive values (Field, 2013). After an item was 
removed, the factor analysis was run again to examine the resulting simple structure solution. Subscale means were calculated for resulting factors and Cronbach's alpha, $\alpha$, was used to calculate the internal consistency of each factor.

Multiple ANOVAs were used to determine whether or not differences existed among demographic groupings (i.e., career stage, teaching division and previous assessment education) with respect to teachers' perceived skill in classroom assessment tasks (i.e., part 2), and teachers' professional learning priorities and preferences in assessment (i.e., part 3). The null hypotheses for these analyses were that means based on demographic categories would not be significantly different. As the demographic category of career stage had three groups, a pairwise comparison was planned in advance and a Bonferroni post-hoc test was selected because the Levene's test indicated that equal variances could be assumed. Comparisons for the other two demographic categories (i.e., teaching division and previous assessment course) only had two sub-groups each and therefore did not require post-hoc testing. Effect sizes for each factor were deduced and presented as percentages of variance explained (i.e., \% variance explained is analogous to $\eta^{2}$, Eta squared, which is the standard measure of effect size for ANOVA)(see Tables 4, 5, and 6).

\section{Results}

\section{Descriptive Analysis}

Table 3 provides descriptive statistics for Parts One, Two, and Three of the ACAI for all participants. In this table, frequencies are presented for Part One, and factor-level means and standard deviations are presented for retained items in Parts Two and Three. Item-level descriptives for the overall sample were also calculated for Parts Two, and Three, and are presented in Tables 4, 5, and 6. Part One of the ACAI, Approaches to Classroom Assessment, presented teachers with five scenarios, and asked them to respond to four questions based on their approach to Assessment Purposes, Assessment Processes, Assessment Fairness, and 
Measurement Theory. With respect to Assessment Purposes, results indicated that teachers in this sample overwhelmingly prioritized a formative assessment approach (84\%) compared to a summative orientation (4\%). In relation to the Assessment Processes, teachers overwhelmingly identified that they respond to assessment scenarios by altering the scoring or administration of assessments instead of attending to assessment design or communicating assessment results. In relation to Assessment Fairness, $60 \%$ of teachers prioritized an equitable approach to grading and assessment (i.e., based on identified exceptionalities) with a substantial percentage of teachers $(37 \%)$ differentiating assessments for diverse groups of learners. Finally, with respect to Measurement Theory, the vast majority (71\%) of teachers emphasized a validity orientation over a reliability orientation.

[Insert Table 3 Here]

Part Two of the ACAI, Perceived Skill in Classroom Assessment, asked teachers to identify their perceived level of perceived skill in assessment (Table 4). The two items with the highest means were, "I provide useful feedback to students to improve their learning" $(M=3.82$, $S D=.92)$, and "I provide timely feedback to students to improve their learning" $(M=3.77, S D$ $=.95)$. The two items with the lowest means were, "I engage students in monitoring their own learning and using assessment information to develop their learning skills and personalized learning plans $(M=3.15, S D=1.10)$, and "I communicate purposes and uses of assessment to parents/guardians when appropriate" $(M=3.04, S D=1.41)$. This suggests that teachers have the greatest perceived skill about providing useful and timely feedback to students, and least perceived skill about engaging parents and students in the assessment process.

Part Three of the ACAI, Assessment Professional Learning Priorities and Preferences, consisted of two sections. In the first section, teachers were asked about their professional learning priorities in assessment, using a five-point scale ( $1=$ very low interest; $5=$ very high 
interest) (see Table 5). The two items with the highest means were, "Cultivating fair assessment conditions for all learners, with sensitivity to student diversity and exceptional learners" $(M=$ 4.07, $S D=.81$ ), and "Analyzing and using assessment information to guide instructional decisions and support student learning" $(M=3.90, S D=.84)$. The two items with the lowest means were, "Scoring assessments in alignment with current assessment theory, principles, and practices" $(M=3.37, S D=.90)$, and "Administering assessments in alignment with current assessment theory, principles, and practices" $(M=3.36, S D=.87)$. This suggests that teachers place a high priority on learning more about integrating fair assessment practices in their classrooms. They place less priority on the alignment of their assessment practices with current assessment theory, principles, and practices. The second section in Part Three asked teachers to identify their professional learning preferences using a five-point scale ( $1=$ not preferred; 5=highly preferred) (see Table 6). The two items with the highest means were, "Classroomembedded collaborative learning/inquiry working with an expert" $(M=3.75, S D=1.07)$, and "Classroom-embedded collaborative learning/inquiry working with colleagues" $(M=3.74, S D=$ 1.04). The two items with the lowest means were, "Online full-length assessment course working independently" $(M=2.46, S D=1.23)$, and "Webinars" $(M=2.27, S D=1.12)$. This suggests that teachers prefer professional learning that takes place in person as opposed to learning through online courses and modules.

\section{Factor Analysis}

Exploratory factor analysis was conducted to determine factor structures and subscales for Part Two and Part Three of the ACAI. Kaiser-Meyer-Olkin (KMO) measures verified the sampling adequacy for the analyses; all KMO values were greater than .66, above the acceptable limit of .5 (Field, 2013). Factor loadings below .4 were suppressed because they did not represent substantive values (Field, 2013). Part Two of the ACAI asked participants to identify 
their perceived skill in various classroom assessment practices. Two factors were identified for this section of the survey (Table 4). The first factor, Monitoring, Analyzing, and Communicating Assessment Results, contained seven items. The internal consistency for this factor was $\alpha=.903$. The second factor, Assessment Design, Implementation and Feedback, contained five items. The internal consistency for this factor was $\alpha=.886$. The correlation between the factors was .770 .

[Insert Table 4 Here]

Part Three of the ACAI, Assessment Professional Learning Priorities and Preferences, consisted of items related to teachers' professional learning priorities in assessment and items related on teachers' preferred modes for professional learning. Two factors were identified for teachers' professional learning priorities in assessment (see Table 5). The first factor, Integrating and Communicating Assessment Practices, contained six items. The internal consistency for this factor was $\alpha=.830$. The second factor, Alignment with Current Assessment Theory, Principles and Practices, contained four items and maintained an internal consistency of $\alpha=.898$. The correlation between the factors was .571 .

[Insert Table 5 Here]

For items that asked teachers about their preferred mode for professional learning, three factors were identified (see Table 6). The first factor, Online Learning, contained five items and an internal consistency of $\alpha=.855$. The second factor, Face-to-Face Group Learning, contained four items with internal consistency of $\alpha=.739$. The third factor, One-on-One Learning, contained two items and the internal consistency was $\alpha=.921$. The correlations among factors ranged from .038 (between online and one-on-one learning) to .451 (between face-to-face group and one-on-one learning).

[Insert Table 6 Here] 


\section{Inferential Analyses}

In order to answer the three research questions, Pearson's chi-square tests and ANOVAs were conducted. The ANOVAs were conducted on subscale means created by adding up (averaging) scores on only those items identified by the factor analysis. Teachers' Approaches to Classroom Assessment (ACAI Part One), Perceived Skill in Classroom Assessment (ACAI Part Two), and Assessment Professional Learning Priorities and Preferences (ACAI Part Three) were analyzed in relation to career stage, teaching division, and previous assessment education. Table 7 provides descriptive statistics for these analyses.

\section{[Insert Table 7 Here]}

For Part One, Approaches to Classroom Assessment, Pearson's chi-square tests of independence were conducted to determine if there were any significant associations between the three demographic variables and the three approaches to assessment based on assessment literacy themes (Assessment Purposes, Assessment Processes, Assessment Fairness, and Measurement Theory). This analysis included the generation of $3 \times 3$ contingency tables (cross-tabs) for career stage (which included three categories: 0-4 years, 5-10 years, and $11+$ years) and 2x3 contingency tables for teaching division and previous assessment experience because they each contained two categories (i.e., $\mathrm{P} / \mathrm{J}$ and $\mathrm{I} / \mathrm{S}$, and course and no course, respectively). There were three possible approaches associated with each assessment literacy theme. As an example, one contingency table would have captured the proportions of the three possible responses under Assessment purposes across the three possible career stages. If significance was found within a $3 \times 3$ or $2 \times 3$ contingency table, post-hoc chi-square tests were then conducted on all $2 \times 2$ combinations from that table to determine specifically where the significant associations existed. Statistically significant associations were found between the Assessment Fairness theme and career stage. This was a 3x3 contingency table with 3 categories for Assessment Fairness (i.e. 
standard, equitable, and differentiated) and 3 categories for career stage (i.e. 0-4 years, 5-10 years, and $11+$ years). Subsequent analysis of $2 \times 2$ tables (e.g. equitable, differentiated x 0-4 years, 5-10 years) resulted in significant associations between teachers with $11+$ years of experience compared to teachers with 0-4 years of experience and teachers with 5-10 years of experience. More specifically, $50 \%$ of teachers with $11+$ years of experience used a differentiated approach, compared to $36.6 \%$ of teachers with $0-4$ years of experience $\left(\chi^{2}(1)=\right.$ $4.17, p=.041)$, and $29.0 \%$ of teachers with $5-10$ years of experience $\left(\chi^{2}(1)=5.568, p=.018\right)$.

For Part Two, Perceived Skill in Classroom Assessment, multiple ANOVAs were used to determine whether or not differences existed between demographic variables (i.e. career stage, teaching division, and previous assessment education) and teachers' perceived skill in assessment tasks and responsibilities. For Part Two, significant differences were found for career stage, and previous assessment experience. In terms of career stage, perceived skill for both factors increased with career experience. Finally, in terms of assessment education, teachers with no course in assessment had greater perceived skill in their assessment practices than teachers who had taken a course. This difference was significant for Monitoring, Analyzing and Communicating $(F(1,402)=5.247, p=.023)$. There were no significant differences for teaching division. In general, however, both Primary/Junior $(\mathrm{P} / \mathrm{J})$ and Intermediate/Senior $(\mathrm{I} / \mathrm{S})$ teachers had greater perceived skill in Design, Implementation, and Feedback than Monitoring, Analyzing and Communicating.

Congruent with Part Two, ANOVAs were used to determine whether or not differences existed between demographic variables (i.e., career stage, teaching division, and previous assessment education) and teachers' professional learning priorities and preferences for Part Three. Significant differences were found for career stage, teaching division and assessment education. Integrating and Communicating Assessment Practices was a significantly greater 
priority for less experienced teachers $(0-4$ years $)(F(2,401)=3.14, p=.046)$ versus teachers with 5-10 years of experience, for $\mathrm{P} / \mathrm{J}$ versus $\mathrm{I} / \mathrm{S}$ teachers $(F(1,402)=5.15, p=.024)$, and for teachers with previous assessment education versus no previous assessment education $(F(1$, $402)=4.938, p=.027$ ). In relation to professional learning priorities, at all levels of experience, teachers placed a higher interest on learning more about Integrating and Communicating Assessment Practices than about Alignment with Assessment Theory, Principles and Practices. With respect to professional learning preferences, significant differences were found for career stage, teaching division and assessment education. Teachers with less experience preferred Oneon-One Learning opportunities $(F(2,383)=12.77, p=.000)$. Teachers in the $\mathrm{P} / \mathrm{J}$ division preferred Face-to-Face Group Learning opportunities significantly more than teachers in the I/S division $(F(1,401)=10.22, p=.001)$. Teachers with no previous assessment education preferred Online Learning significantly more than teachers with previous assessment education $(F(1,401)=8.068, p=.005)$. Online Learning was the least preferred for all demographics.

\section{Discussion}

The overarching purpose of this research was to use a new instrument (i.e., ACAI) based on the revised Classroom Assessment Standards (JCSEE, 2015) to measure teachers' approaches to classroom assessment in relation to existing accountability and standards-based education frameworks. Specifically, this research aimed to analyze teachers': (a) approaches to classroom assessment scenarios, (b) perceived skill in assessment tasks and responsibilities, and (c) professional learning preferences and priorities, based on their career stage, teaching division, and previous assessment education. Given the lack of classroom assessment literacy measures grounded in cotemporary assessment standards and the centrality of classroom assessment in supporting students' learning (Author; Brookhart, 2011; Gotch \& French 2014), this research provides important preliminary findings that serve to characterize teachers' current approaches to 
assessment within the existing context of public education. Furthermore, these findings provide a basis for constructing targeted pre-service assessment education and in-service professional learning opportunities aimed at enhancing teachers' assessment literacy, with the ultimate goal of enhancing students' learning and achievement.

Based on a sample of 404 teachers from across Canada and the United States, this study contributes initial evidence of how teachers approach classroom assessment with respect to four dimensions: Assessment Purposes, Assessment Processes, Assessment Fairness, and Measurement Theory. In contrast to previous research (Brown \& Remesal, 2012; Mertler, 2004), no significant differences in teachers' approaches to assessment were found based on teaching division (i.e., Primary/Junior vs. Intermediate/Senior) or previous assessment education. One significant difference was observed based on teachers' career experience. Specifically, teachers' approaches to Assessment Fairness became more differentiated with increased years of teaching experience. Early career teachers tend toward a standardized approach with mid-career teachers tending to employ an equitable approach. The most experienced teachers in this sample generally favoured a differentiated approach. Congruent with previous research (Cowan, 2009; Smith et al., 2014), we understand this finding to suggest that teachers adopt a more complex, student-focused approach to assessment fairness as they gain in-service experience (i.e., informal learning through classroom implementation and experimentation and formal professional learning opportunities). For example, an early career teacher may be inclined to give the same summative assessment task to every student but, through in-service experience and professional learning, this same teacher may begin to accommodate identified students on summative assessments, and eventually move toward providing differentiated summative assessment tasks for all students.

Despite a significant change in teachers' approaches to Assessment Fairness, our overall findings with respect to teachers' approaches to assessment suggest that the approaches teachers 
adopt are relatively stable, regardless of career stage, teaching division, and previous assessment education. This finding provides important evidence to inform efforts aimed at enhancing teachers' assessment literacy through assessment education (i.e., pre-service courses and inservice professional learning). Specifically, this finding highlights that teachers hold relatively established assessment orientations that may be difficult to change once in-service. Accordingly, assessment education at the pre-service level must provide teacher candidates with a strong foundation in contemporary assessment standards and practices. As the assessment education variable in this study did not differentiate between pre-service training in assessment and various in-service professional learning opportunities, it is not surprising that a significance difference was not found in our study. Future research is needed that more accurately measures the value and sustained benefits of specific in-service assessment education models.

In contrast with teachers' approaches to assessment, teachers' perceived skill in assessment tasks and responsibilities (i.e., Monitoring, Analyzing, and Communicating and Design, Implementation, and Feedback), were significantly influenced by demographic characteristics, specifically career stage and previous assessment education. Not surprisingly, changes in teachers' perceived skill increased significantly with career experience-more experienced teachers reported greater skill in both Monitoring, Analyzing, and Communicating and Design, Implementation, and Feedback compared to less experienced teachers. Interestingly, teachers with no courses in assessment reported a higher level of skill in assessment than those with previous assessment education, although this difference was only significant for the Monitoring, Analyzing, and Communicating factor. While this finding may seem counterintuitive, we argue that assessment education courses help teachers begin to develop awareness and deeper understanding of the complexities associated with contemporary conceptions of assessment literacy. Becoming aware of these complexities may actually negatively impact teachers' self- 
reported skill in assessment literacies when compared to teachers who do not have previous assessment education experiences and may not yet have this awareness (DeLuca \& Klinger, 2010; Volante \& Fazio, 2007).

With respect to professional learning priorities in assessment, the teachers in our sample prioritized professional learning about Integrating and Communicating Assessment Processes over Alignment with Assessment Theory, Principles, and Practices. This suggests that these teachers recognize the importance of learning about contemporary approaches to classroom assessment (e.g., choosing and communicating assessment purposes and processes to students and parents; integrating and using formative assessment to guide instruction and support students' learning; and cultivating fair assessment conditions for students) as compared to learning about more traditional assessment tasks (e.g., constructing, administering, scoring, and interpreting assessments). Moreover, learning about Integrating and Communicating Assessment Processes was particularly important for early career stage teachers and teachers with previous assessment education. These findings highlight that assessment education helps teachers become aware of the complexities associated with assessment literacy, and points to the need for ongoing, job-embedded professional learning initiatives that provide teachers with opportunities to enhance their assessment literacy within the classroom context - both throughout their careers and, especially, in their early years on the job (Harrison, 2005; Wiliam, Lee, Harrison \& Black, 2004; Lee \& Wiliam, 2005; MacLellan, 2004; Volante \& Fazio, 2007).

In terms of professional learning preferences, we found significant differences based on all three demographics — career stage, teaching division, and previous assessment education. Less experienced teachers preferred One-on-One Learning more than their experienced counterpartsa finding that is aligned with research advocating mentoring models of professional learning for early career teachers (Feeney-Jonson, 2008). Primary/Junior teachers preferred Face-to-Face 
Group Learning significantly more than Intermediate/Senior teachers, possibly reflecting the currently emerging culture of collaborative professional learning in secondary schools that has been previously established in elementary contexts. Overall, Online Learning opportunities were least preferred suggesting that teachers tend to value learning opportunities that are job-embedded with supported implementation of new instructional practices (DeLuca et al., 2015). Nonetheless, teachers with no assessment education preferred Online Learning more than teachers with previous assessment education. This finding supports our earlier conclusion that teachers with no previous assessment education may have limited understandings of the complexities associated with contemporary classroom assessment and, therefore, may underestimate the importance of ongoing, job-embedded professional learning opportunities situated in the context of practice.

\section{Implications for Research and Practice}

Taken together, our study indicated four key takeaway messages for research and practice focused on enhancing and supporting teachers' assessment literacy in order to meet accountability demands within the current context of standards-based education.

1. While teachers' perceived skill in assessment tasks and responsibilities is impacted by career stage and previous assessment education, their approaches to assessment may be more fixed (i.e., without intervention teachers hold consistent orientations toward their priorities in classroom assessment). Therefore, these approaches provide valuable insights into how teachers understand and implement assessment in their classrooms. When supporting teachers' development of assessment literacy through various pre-service courses and in-service professional learning opportunities, we must recognize and support not only teachers' current assessment literacies but also their individual approaches to classroom assessment. Teachers' approaches to assessment may have a considerable 
impact on how they experience and integrate assessment education into their instructional practice.

2. Professional learning opportunities in assessment need to be targeted and differentiated, based on teachers' career stage and previous assessment education. In particular, emphasizing contemporary assessment practices (e.g., choosing and communicating assessment purposes and processes to students and parents; integrating and using formative assessment to guide instruction and support students' learning; and cultivating fair assessment conditions for students) over more traditional assessment tasks (e.g., constructing, administering, scoring, and interpreting assessments) is a priority, especially for early career teachers and those with previous assessment education. Consequently, we must consider teachers' career stage and previous assessment education when structuring professional learning opportunities in assessment in order to maximize the impact of these efforts on teachers' enhanced assessment literacy.

3. Professional learning opportunities for teachers need to be embedded in the context of practice, rather than administered online. Given the current trend toward online and blended professional learning opportunities (i.e., combining face-to-face and online learning), this information is important precisely because it is counter to a growing trend. Teachers prefer collaborative, job-embedded professional learning opportunities that allow them to develop their assessment literacy through supported implementation within the classroom context. Moreover, for early career teachers, and teachers new to contemporary assessment practices, one-on-one mentoring models may facilitate the development of foundational understanding and perceived skill prior to engagement in collaborative professional learning models. 
4. When measuring teachers' assessment literacy for research purposes, we must use instruments grounded in contemporary assessment standards that not only measure teachers' perceived skill in assessment literacy, but also consider how teachers approach various classroom assessment scenarios. Because perceived skill in assessment is influenced by demographic characteristics, career stage in particular, measuring teachers' approaches to assessment may allow us to draw more valid conclusions about how teachers engage assessment theories, principles, and practices. Ultimately, these types of measures will contribute to a deeper understanding of how teachers' assessment literacy develops through professional experience and assessment education.

Despite the importance of these findings, we must acknowledge some limitations of our study. First and foremost, our sample consisted of predominantly female, inexperienced teachers with previous assessment education; we cannot be certain this is representative of the current teaching population. Depending upon context, teaching population may have greater distribution of experienced professionals. Hence, the findings from this study need to be considered in light of this limitations with recognition that findings may not be generalizable to larger populations or different contexts. Second, this instrument is a self-report measure. Future research should advance the use of the instrument to measure within school consistencies through teacher observations and assessment samples to enable discussions about priorities and challenges of enacted assessment practices. Lastly, despite strong reliability statistics, a construct validation process, and a pilot phase, data for this study was based on the first large-scale administration of the ACAI - a new assessment literacy measure. Consequently, this study marks the first step in using the ACAI to examine teachers' approaches to assessment. Additional use of this instrument will reinforce its reliability and validity across contexts. 


\section{References}

American Federation of Teachers, National Council on Measurement in Education, \& National Education Association (1990). Standards for teacher competence in educational assessment of students. Washington, DC: National Council on Measurement in Education.

Bennett, R. E. (2011). Formative assessment: A critical review. Assessment in Education: Principles, Policy \& Practice, 18(1), 5-25.

Birenbaum, M., DeLuca, C., Earl, L., Heritage, M., Klenowski, V., Looney, A., Smith, K., Timperley, H., Volante, L., \& Wyatt-Smith, C. (2015). International trends in the implementation of assessment: Implications for policy and practice. Policy Futures in Education, 13(1), 117-140.

Black, P., \& Wiliam, D. (1998). Inside the black box: Raising standards through classroom assessment. Assessment in Education, 5(1), 7-74.

Brookhart, S. (2011). Educational assessment knowledge and skills for teachers. Educational Measurement: Issues and Practice, 30, 3-12.

Brown, G. T. (2004). Teachers' conceptions of assessment: Implications for policy and professional development. Assessment in Education: Principles, Policy \& Practice, 11(3), 301-318.

Brown, G., \& Harris, L. (2009). Unintended consequences of using tests to improve learning: How improvement-oriented resources heighten conceptions of assessment as school accountability. Journal of Multi-Disciplinary Evaluation, 6(12), 68-91.

Brown, G. T., \& Remesal, A. (2012). Prospective teachers' conceptions of assessment: A crosscultural comparison. The Spanish Journal of Psychology, 15(1), 75-89.

Brown, G. T., Hui, S. K., Flora, W. M., \& Kennedy, K. J. (2011). Teachers' conceptions of 
assessment in Chinese contexts: A tripartite model of accountability, improvement, and irrelevance. International Journal of Educational Research, 50(5), 307-320.

Campbell, C., Murphy, J. A., \& Holt, J. K. (2002, October). Psychometric analysis of an assessment literacy instrument: Applicability to pre-service teachers. Paper presented at the annual meeting of the Mid-Western Educational Research Association, Columbus, OH.

Cowan, E. M. (2009). Implementing formative assessment: Student teachers' experiences on placements. Teacher Development, 13(1), 71-84.

DeLuca, C. (2012). Preparing teachers for the age of accountability: Toward a framework for assessment education. Teacher Education Yearbook XXI: A Special Issue of Action in Teacher Education, 34(5/6), 576-591.

DeLuca, C., \& Bellara, A. (2013). The current state of assessment education: Aligning policy, standards, and teacher education curriculum. Journal of Teacher Education, 64(4), 356372.

DeLuca, C., \& Klinger, D. A. (2010). Assessment literacy development: Identifying gaps in teacher candidates' learning. Assessment in Education: Principles, Policy \& Practice, $17(4), 419-438$.

DeLuca, C., Klinger, D., Pyper, J., Shulha, L., \& Woods, J. (2015). Building school district capacity in assessment for learning: A study on the effectiveness of an instructional rounds professional learning approach. Assessment in Education: Principles, Policy and Practice, 22(1), 122-139.

DeLuca, C., LaPointe-McEwan, D., \& Luhanga, U. (2016). Teacher assessment literacy: a review of international standards and measures. Educational Assessment, Evaluation and Accountability, 28(2), 251-272.

Earl, L. (2003). Assessment as learning. Thousand Oaks, CA: Corwin. 
Feeney-Jonson, K. (2008). Being an effective mentor: How to help beginning teachers succeed (2nd ed.). Thousand Oaks, CA: Corwin Press.

Field, A. (2013). Discovering statistics using IBM SPSS statistics (4th ed). London, UK: Sage. Gardner, J. (2006). Assessment for learning: A compelling conceptualization. In J. Gardner (Ed.), Assessment and Learning (pp. 197-204). Los Angeles, CA: Sage.

Gotch, C. M., \& French, B. F. (2014). A systematic review of assessment literacy measures. Educational Measurement: Issues and Practice, 33, 14-18.

Harlen, W. (2006). On the relationship between assessment for formative and summative purposes. In J. Gardner (Ed.), Assessment and learning (pp. 87-103). Los Angeles, CA: Sage.

Harrison, C. (2005). Teachers developing assessment for learning: Mapping teacher change. Teacher Development, 9(2), 255-263.

Hirschfeld, G. H., \& Brown, G. T. (2009). Students' conceptions of assessment: Factorial and structural invariance of the SCoA across sex, age, and ethnicity. European Journal of Psychological Assessment, 25(1), 30-38.

Joint Committee for Standards on Educational Evaluation. (2015). Classroom assessment standards: Practices for PK-12 teachers. Retrieved from http://www.jcsee.org/theclassroom-assessment-standards-new-standards

Lee, C., \& Wiliam, D. (2005). Studying changes in the practice of two teachers developing assessment for learning. Teacher Development, 9(2), 265-283.

MacLellan, E. (2004). Initial knowledge states about assessment: Novice teachers' conceptualizations. Teaching and Teacher Education, 20, 523-535. 
Mertler, C. A. (2003). Pre-service versus in-service teachers' assessment literacy: Does classroom experience make a difference? In Annual meeting of the Mid-Western Educational Research Association, Columbus, $\mathrm{OH}$.

Mertler, C. A. (2004). Secondary teachers' assessment literacy: Does classroom experience make a difference?. American Secondary Education, 49-64.

Mertler, C. A. (2009). Teachers' assessment knowledge and their perceptions of the impact of classroom assessment professional development. Improving Schools, 12(2), 101-113. doi: $10.1177 / 1365480209105575$

Mertler, C. A., \& Campbell, C. (2005). Measuring Teachers' Knowledge \& Application of Classroom Assessment Concepts: Development of the Assessment Literacy Inventory. In Annual meeting of the American Educational Research Association, Montreal, QC.

Moss, P. A. (2003). Reconceptualizing validity for classroom assessment. Educational Measurement: Issues and Practice, 22(4), 13-25.

Newton, P. E. (2007). Clarifying the purposes of educational assessment. Assessment in Education, 14(2), 149-170.

O’Sullivan, R. S., \& Johnson, R. L. (1993, April). Using performance assessments to measure teachers' competence in classroom assessment. Paper presented at the annual meeting of the American Educational Research Association, Atlanta, GA.

Parkes, J. (2007). Reliability as argument. Educational Measurement: Issues and Practice, 26(4), 2-10.

Plake, B., Impara, J., \& Fager, J. (1993). Assessment competencies of teachers: A national survey. Educational Measurement: Issues and Practice, 12(4), 10-39. doi:10.1111/j.17453992.1993.tb00548.x 
Popham, W. J. (2004). Why assessment illiteracy is professional suicide. Educational Leadership, 62, 82-83.

Popham, W. J. (2013). Classroom assessment: What teachers need to know (7th ed.). Boston, MA: Pearson.

Shepard, L. A. (2000). The role of classroom assessment in teaching and learning. Educational Researcher, 29(7), 4-14.

Smith, L. F., Hill, M. F., Cowie, B., \& Gilmore, A. (2014). Preparing teachers to use the enabling power of assessment. In C. Wyatt-Smith, V. Klenowski \& P. Colbert (Eds.). Designing assessment for quality learning (pp. 303-323). Heidelberg, NE: Springer.

Stobart, G. (2008). Testing times: The uses and abuses of assessment. New York, NY: Routledge.

Swaffield, S. (2011). Getting to the heart of authentic assessment for learning. Assessment in Education: Principles, Policy \& Practice, 18(4), 433-449.

Taras, M. (2007). Assessment for learning: Understanding theory to improve practice. Journal of Further and Higher Education, 31(4), 363-371.

Tabachnick, B. G., \& Fidell, L. S. (2007). Using multivariate statistics, (5th ed). Boston, MA: Pearson.

Volante, L., \& Fazio, X. (2007). Exploring teacher candidates' assessment literacy: Implications for teacher education reform and professional development. Canadian Journal of Education, 30, 749-770.

Willis, J. (2010). Assessment for learning as a participatory pedagogy. Assessment Matters, 2 , 65-84. 
Willis, J., Adie, L., \& Klenowski, V. (2013). Conceptualising teachers' assessment literacies in an era of curriculum and assessment reform. The Australian Educational Researcher, $40(2), 241-256$. 
Table 1

Frequencies of Participant Demographics $(n=404)$

\begin{tabular}{llc}
\hline Demographic & & Frequency (\%) \\
\hline Gender & Male & 16.1 \\
& Female & 83.9 \\
\hline Age & $20-25$ & 35.7 \\
& $26-35$ & 36.5 \\
& $36-45$ & 14.9 \\
& $46-55$ & 10.9 \\
& over 55 & 3.0 \\
\hline School System & Public & 66.3 \\
& Catholic & 13.6 \\
& Independent & 20.1 \\
\hline Career Stage & $0-4$ years & 63.6 \\
& 5-10 years & 17.8 \\
& 11+ years & 18.6 \\
\hline Teaching Division & Primary/Junior (P/J) & 54.4 \\
& Intermediate/Senior (I/S) & 45.5 \\
\hline Assessment Education & Course in assessment & 79.0 \\
& No course in assessment & 20.5 \\
\hline
\end{tabular}


Table 2

Assessment Literacy Themes with associated Approaches to Assessment

\begin{tabular}{llll}
\hline & & \multicolumn{2}{c}{ Approaches to Assessment } \\
\cline { 2 - 4 } $\begin{array}{l}\text { Assessment } \\
\text { Literacy Theme }\end{array}$ & Approach A & Approach B & Approach C \\
\hline $\begin{array}{l}\text { Assessment } \\
\text { Purposes }\end{array}$ & $\begin{array}{l}\text { Assessment of } \\
\text { Learning/Summative }\end{array}$ & $\begin{array}{l}\text { Assessment for } \\
\text { Learning/Formative }\end{array}$ & $\begin{array}{l}\text { Assessment } a s \\
\text { Learning }\end{array}$ \\
$\begin{array}{l}\text { Assessment } \\
\text { Processes }\end{array}$ & Designing & $\begin{array}{l}\text { Administration and } \\
\text { Scoring }\end{array}$ & Communication \\
Assessment Fairness & Standard Treatment & Equitable Treatment & $\begin{array}{l}\text { Differentiated } \\
\text { Approach }\end{array}$ \\
$\begin{array}{l}\text { Measurement } \\
\text { Theory }\end{array}$ & Reliability & Validity & $\begin{array}{l}\text { Reliability and } \\
\text { Validity }\end{array}$ \\
\hline
\end{tabular}


Table 3

Descriptive Statistics (Frequencies, Means and Standard Deviations) for ACAI Parts One, Two, and Three for All Participants

\begin{tabular}{|c|c|c|}
\hline \multicolumn{3}{|l|}{$\begin{array}{l}\text { Part One: Approaches to } \\
\text { Assessment }\end{array}$} \\
\hline \multirow[t]{3}{*}{ Assessment Purposes } & Assessment of Learning/Summative & 4.7 \\
\hline & Assessment for learning/Formative & 83.7 \\
\hline & Assessment as learning & 11.6 \\
\hline \multirow[t]{3}{*}{ Assessment Processes } & Designing & 12.6 \\
\hline & Administration and scoring & 78.7 \\
\hline & Communicating & 8.7 \\
\hline \multirow[t]{3}{*}{ Assessment Fairness } & Standard Treatment & 2.5 \\
\hline & Equitable Treatment & 60.4 \\
\hline & Differentiated Approach & 37.1 \\
\hline \multirow[t]{4}{*}{ Measurement } & Reliability & 2.2 \\
\hline & Validity & 70.8 \\
\hline & Reliability and Validity & 27.0 \\
\hline & & $M(S D)$ \\
\hline \multirow[t]{2}{*}{$\begin{array}{l}\text { Part Two: Perceived Skill } \\
\text { in Assessment }\end{array}$} & $\begin{array}{l}\text { Monitoring, Analyzing, and } \\
\text { Communicating ( } 7 \text { items) }\end{array}$ & $3.31(.94)$ \\
\hline & $\begin{array}{l}\text { Design, Implementation, and Feedback ( } 5 \\
\text { items) }\end{array}$ & $3.70(.78)$ \\
\hline \multirow{3}{*}{$\begin{array}{l}\text { Part Three (A): } \\
\text { Professional Learning } \\
\text { Priorities }\end{array}$} & Integrating and Communicating & $3.74(.67)$ \\
\hline & Assessment Practices (6 items) & \\
\hline & $\begin{array}{l}\text { Alignment with Assessment Theory, } \\
\text { Principles, and Practices ( } 4 \text { items) }\end{array}$ & $3.42(.77)$ \\
\hline \multirow{2}{*}{$\begin{array}{l}\text { Part Three (B): } \\
\text { Professional Learning } \\
\text { Preferences }\end{array}$} & Online Learning (5 items) & $2.58(.97)$ \\
\hline & $\begin{array}{l}\text { Face-to-Face Group Learning ( } 4 \text { items) } \\
\text { One-on-One Learning ( } 2 \text { items) }\end{array}$ & $\begin{array}{c}3.43(.84) \\
3.40(1.15) \\
\end{array}$ \\
\hline
\end{tabular}


Table 4

Descriptive Statistics (Item Means and Standard Deviations) and Factor Loadings for ACAI Part

Two: Perceived Skill in Classroom Assessment

\begin{tabular}{|c|c|c|c|}
\hline Assessment Practices & $M(S D)$ & $\begin{array}{l}\text { Monitoring, } \\
\text { analyzing, and } \\
\text { communicating } \\
\text { assessment } \\
\text { results } \\
\end{array}$ & $\begin{array}{l}\text { Assessment } \\
\text { design, } \\
\text { implementation } \\
\text { and feedback }\end{array}$ \\
\hline $\begin{array}{l}\text { 1. My practices have a clear purpose (e.g., diagnostic, } \\
\text { formative, summative) that supports teaching and } \\
\text { learning towards achievement of curriculum } \\
\text { expectations. }\end{array}$ & $3.52(.90)$ & & .682 \\
\hline $\begin{array}{l}\text { 2. My assessment practices align with the established } \\
\text { curriculum expectations }\end{array}$ & $3.76(.92)$ & & .698 \\
\hline $\begin{array}{l}\text { 6. I provide adequate student preparation for } \\
\text { assessments in terms of resources, time, and } \\
\text { learning opportunities. }\end{array}$ & $3.72(.96)$ & & .661 \\
\hline $\begin{array}{l}\text { 8. I communicate purposes and uses of assessment to } \\
\text { parents/guardians when appropriate. }\end{array}$ & $3.04(1.41)$ & .580 & \\
\hline $\begin{array}{l}\text { 14. I monitor and revise my assessment practice to } \\
\text { improve the quality of my instructional practice. }\end{array}$ & $3.66(1.05)$ & .604 & \\
\hline $\begin{array}{l}\text { 16. I am able to use a variety of strategies to analyze } \\
\text { test and assessment results at both student and } \\
\text { class levels. }\end{array}$ & $3.35(1.15)$ & .781 & \\
\hline $\begin{array}{l}\text { 18. I provide timely feedback to students to improve } \\
\text { their learning. }\end{array}$ & $3.77(.95)$ & & .760 \\
\hline $\begin{array}{l}\text { 19. I provide useful feedback to students to improve } \\
\text { their learning. }\end{array}$ & $3.82(.92)$ & & .843 \\
\hline $\begin{array}{l}\text { 22. My reports are based on a sufficient body of } \\
\text { evidence and provide a summary of student } \\
\text { learning toward meeting curriculum expectations. }\end{array}$ & $3.37(1.32)$ & .638 & \\
\hline $\begin{array}{l}\text { 24. I engage students in monitoring their own learning } \\
\text { and using assessment information to develop their } \\
\text { learning skills and personalized learning plans. }\end{array}$ & $3.15(1.10)$ & .694 & \\
\hline $\begin{array}{l}\text { 25. I have thought deeply about my approach to } \\
\text { assessment. }\end{array}$ & $3.44(1.06)$ & .881 & \\
\hline $\begin{array}{l}\text { 26. I am able to articulate my personal philosophy of } \\
\text { assessment recognizing its alignment and } \\
\text { misalignment with assessment policies and theory. }\end{array}$ & $3.25(1.15)$ & .785 & \\
\hline$\%$ of variance explained $*$ & & $58.7 \%$ & $8.17 \%$ \\
\hline Internal consistency & & .903 & .886 \\
\hline \multirow[t]{2}{*}{ Correlation Matrix } & Monitoring & 1 & .770 \\
\hline & Assessment & .770 & 1 \\
\hline
\end{tabular}

Note. Factor loadings $<.40$ were suppressed. Scale: $1=$ novice, $2=$ beginner, $3=$ proficient, 4=competent, 5=expert, NA=don't know

$* \%$ variance explained is analogous to $\eta^{2}$ (Eta squared), which is the standard measure of effect size for ANOVA 
Table 5

Descriptive Statistics (Item Means and Standard Deviations) and Factor Loadings for ACAI Part

Three (A): Assessment Professional Learning Priorities

\begin{tabular}{|c|c|c|c|}
\hline Assessment Professional Learning Priorities & $M(S D)$ & $\begin{array}{l}\text { Integrating and } \\
\text { communicating } \\
\text { assessment } \\
\text { practices }\end{array}$ & $\begin{array}{l}\text { Alignment with } \\
\text { current } \\
\text { assessment } \\
\text { theory, } \\
\text { principles, and } \\
\text { practices } \\
\end{array}$ \\
\hline $\begin{array}{l}\text { 1. Choosing the appropriate purpose of assessment } \\
\text { (e.g., diagnostic, formative, summative) based on } \\
\text { instructional goals and assessment }\end{array}$ & $3.42(.96)$ & .592 & \\
\hline $\begin{array}{l}\text { 2. Constructing assessments in alignment with current } \\
\text { assessment theory, principles, and practices. }\end{array}$ & $3.44(.87)$ & & .844 \\
\hline $\begin{array}{l}\text { 3. Administering assessments in alignment with } \\
\text { current assessment theory, principles, and } \\
\text { practices. }\end{array}$ & $3.36(.87)$ & & .860 \\
\hline $\begin{array}{l}\text { 4. Scoring assessments in alignment with current } \\
\text { assessment theory, principles, and practices. }\end{array}$ & $3.37(.90)$ & & .823 \\
\hline $\begin{array}{l}\text { 5. Interpreting and using assessment information in } \\
\text { alignment with current assessment theory, } \\
\text { principles, and practices. }\end{array}$ & $3.52(.89)$ & & .759 \\
\hline $\begin{array}{l}\text { 7. Communicating assessment purposes, processes, } \\
\text { and results to students, parents/guardians, and } \\
\text { other stakeholders. }\end{array}$ & $3.67(.91)$ & .721 & \\
\hline $\begin{array}{l}\text { 8. Cultivating fair assessment conditions for all } \\
\text { learners, with sensitivity to student diversity and } \\
\text { exceptional learners. }\end{array}$ & $4.07(.81)$ & .774 & \\
\hline $\begin{array}{l}\text { 9. Disclosing accurate information about assessments. } \\
\text { Protecting the rights and privacy of students that } \\
\text { are assessed. }\end{array}$ & $3.48(1.06)$ & .610 & \\
\hline $\begin{array}{l}\text { 11. Integrating formative assessment (including } \\
\text { assessment for and as learning) during instruction } \\
\text { to guide next steps in teaching a }\end{array}$ & $3.88(.85)$ & .653 & \\
\hline $\begin{array}{l}\text { 12. Analyzing and using assessment information to } \\
\text { guide instructional decisions and support student } \\
\text { learning. }\end{array}$ & $3.90(.84)$ & .656 & \\
\hline$\%$ of variance explained $*$ & & $48.1 \%$ & $15.5 \%$ \\
\hline Internal consistency & & .830 & .898 \\
\hline Correlation Matrix & $\begin{array}{l}\text { Integrating... } \\
\text { Alignment... }\end{array}$ & $\begin{array}{c}1 \\
.571\end{array}$ & $\begin{array}{c}.571 \\
1\end{array}$ \\
\hline
\end{tabular}

Note. Factor loadings $<.40$ were suppressed. Scale: $1=$ very low, $2=$ low, $3=$ moderate, $4=$ high, $5=$ very high

$* \%$ variance explained is analogous to $\eta^{2}$ (Eta squared), which is the standard measure of effect size for ANOVA 
Table 6

Descriptive Statistics (Item Means and Standard Deviations) and Factor Loadings for ACAI Part

Three (B): Assessment Professional Learning Preferences

\begin{tabular}{|c|c|c|c|c|}
\hline $\begin{array}{l}\text { Assessment Professional Learning } \\
\text { Preferences }\end{array}$ & $M(S D)$ & $\begin{array}{c}\text { Online } \\
\text { Learning }\end{array}$ & $\begin{array}{l}\text { Face-to- } \\
\text { Face, Group } \\
\text { Learning }\end{array}$ & $\begin{array}{l}\text { One-on-One } \\
\text { Learning }\end{array}$ \\
\hline $\begin{array}{l}\text { 1. Face-to-face full-length assessment } \\
\text { course with a cohort of other } \\
\text { practicing teachers }\end{array}$ & $2.92(1.22)$ & & .407 & \\
\hline $\begin{array}{l}\text { 2. Face-to-face short assessment module } \\
\text { with a cohort of other practicing } \\
\text { teachers }\end{array}$ & $3.29(1.11)$ & & .437 & \\
\hline $\begin{array}{l}\text { 3. Online full-length assessment course } \\
\text { working independently }\end{array}$ & $2.46(1.23)$ & .757 & & \\
\hline $\begin{array}{l}\text { 4. Online full-length assessment course } \\
\text { working with cohort of other } \\
\text { practicing teachers }\end{array}$ & $2.57(1.24)$ & .767 & & \\
\hline $\begin{array}{l}\text { 5. A series of short online assessment } \\
\text { modules offered as independent } \\
\text { studies }\end{array}$ & $2.80(1.25)$ & .820 & & \\
\hline $\begin{array}{l}\text { 6. A series of short online assessment } \\
\text { modules working with cohort of } \\
\text { practicing teachers }\end{array}$ & $2.81(1.24)$ & .779 & & \\
\hline $\begin{array}{l}\text { 7. Classroom-embedded collaborative } \\
\text { learning/inquiry working with } \\
\text { colleagues }\end{array}$ & $3.74(1.04)$ & & .777 & \\
\hline $\begin{array}{l}\text { 8. Classroom-embedded collaborative } \\
\text { learning/inquiry working an expert. }\end{array}$ & $3.75(1.07)$ & & .903 & \\
\hline 10. Webinars & $2.27(1.12)$ & .541 & & \\
\hline $\begin{array}{l}\text { 11. One-on-one mentoring with peer } \\
\text { teacher. }\end{array}$ & $3.38(1.21)$ & & & .875 \\
\hline $\begin{array}{l}\text { 12. One-on-one mentoring with a } \\
\text { support teacher. }\end{array}$ & $3.41(1.17)$ & & & .958 \\
\hline$\%$ of variance explained* & & $29.6 \%$ & $26.6 \%$ & $10.6 \%$ \\
\hline Internal consistency & & .855 & .739 & .921 \\
\hline \multirow[t]{3}{*}{ Correlation Matrix } & Online & 1 & -.113 & .038 \\
\hline & Face to face & -.113 & 1 & .451 \\
\hline & One-on-one & .038 & .451 & 1 \\
\hline
\end{tabular}

Note. Factor loadings $<.40$ were suppressed. Scale: $1=$ not preferred, $2=$ somewhat preferred, $3=$ moderately preferred, $4=$ preferred, $5=$ highly preferred

$* \%$ variance explained is analogous to $\eta^{2}$ (Eta squared), which is the standard measure of effect size for ANOVA 
Table 7

Descriptive statistics for ACAI Part One (Response Totals) and for ACAI Parts Two and Three (Mean and Standard Deviation on a Five- point Scale) by Career Experience, Teaching Division, and Assessment Education

\begin{tabular}{|c|c|c|c|c|c|c|c|c|}
\hline & & \multicolumn{3}{|c|}{ Career Stage } & \multicolumn{2}{|c|}{ Teaching Division } & \multicolumn{2}{|c|}{$\begin{array}{c}\text { Previous Assessment } \\
\text { Education }\end{array}$} \\
\hline & & $\begin{array}{c}0-4 \text { years } \\
(n=246)\end{array}$ & $\begin{array}{c}\text { 5-10 years } \\
(n=69)\end{array}$ & $\begin{array}{l}>10 \text { years } \\
\quad(n=72)\end{array}$ & $\begin{array}{c}\mathbf{P} / \mathbf{J} \\
(n=194)\end{array}$ & $\begin{array}{c}I / S \\
(n=162)\end{array}$ & $\begin{array}{l}\text { Course } \\
(\mathrm{n}=321)\end{array}$ & $\begin{array}{c}\text { No Course } \\
(n=83)\end{array}$ \\
\hline \multicolumn{9}{|c|}{ Part One: Approaches to Assessment } \\
\hline \multirow[t]{3}{*}{ Assessment Purposes } & Summative & 5.3 & 5.8 & 2.8 & 3.6 & 8.0 & 7.2 & 4.0 \\
\hline & Formative & 85.8 & 81.2 & 77.8 & 86.6 & 81.5 & 79.5 & 84.7 \\
\hline & Assessment as learning & 8.9 & 13.0 & 19.4 & 9.8 & 10.5 & 13.3 & 11.2 \\
\hline \multirow{3}{*}{$\begin{array}{l}\text { Assessment } \\
\text { Processes }\end{array}$} & Designing & 11.0 & 14.5 & 18.1 & 12.4 & 12.3 & 14.5 & 12.1 \\
\hline & $\begin{array}{l}\text { Administration and } \\
\text { scoring }\end{array}$ & 79.7 & 78.3 & 73.6 & 78.9 & 81.5 & 75.9 & 79.4 \\
\hline & Communicating & 9.3 & 7.2 & 8.3 & 8.8 & 6.2 & 9.6 & 8.4 \\
\hline \multirow[t]{3}{*}{ Assessment Fairness } & Standard & 1.6 & 5.8 & 1.4 & 2.1 & 3.7 & 2.4 & 2.5 \\
\hline & Equitable & 61.8 & 65.2 & 48.6 & 58.8 & 63.6 & 63.9 & 59.5 \\
\hline & Differentiated & 36.6 & 29.0 & 50.0 & 39.2 & 32.7 & 33.7 & 38.0 \\
\hline \multirow[t]{3}{*}{ Measurement Theory } & Reliability & 1.6 & 2.9 & 2.8 & 1.0 & 4.3 & 2.4 & 2.2 \\
\hline & Validity & 72.4 & 75.4 & 68.1 & 69.6 & 71.0 & 69.9 & 71.0 \\
\hline & Reliability and validity & 26.0 & 21.7 & 29.2 & 29.4 & 24.7 & 27.7 & 26.8 \\
\hline \multirow[t]{2}{*}{$\begin{array}{l}\text { Part Two: Perceived } \\
\text { Skill in Assessment }\end{array}$} & $\begin{array}{l}\text { Monitoring, Analyzing, } \\
\text { and Communicating }\end{array}$ & $3.00(.91)^{*}$ & $3.64(.77)^{*}$ & $4.09(.66)^{*}$ & $3.32(.89)$ & $3.27(.98)$ & $3.26(.95)^{*}$ & $3.52(.86)^{*}$ \\
\hline & $\begin{array}{l}\text { Design, Implementation, } \\
\text { and Feedback }\end{array}$ & $3.51(.78)^{*}$ & $3.83(.59)^{*}$ & $4.16(.69)^{*}$ & $3.63(.75)$ & $3.74(.80)$ & $3.67(.80)$ & $3.78(.68)$ \\
\hline \multirow{3}{*}{$\begin{array}{l}\text { Part Three (A): } \\
\text { Professional } \\
\text { Learning Priorities }\end{array}$} & Integrating and & $3.80(.62)^{*}$ & $3.58(.76)^{*}$ & $3.69(.72)$ & $3.75(.67)^{*}$ & $3.65(.68)^{*}$ & $3.77(.64)^{*}$ & $3.59(.74)^{*}$ \\
\hline & $\begin{array}{l}\text { Communicating } \\
\text { Assessment Practices }\end{array}$ & & & & & & & \\
\hline & $\begin{array}{l}\text { Alignment with } \\
\text { Assessment Theory, } \\
\text { Principles, and Practices }\end{array}$ & $3.40(.75)$ & $3.41(.87)$ & $3.51(.79)$ & $3.41(.80)$ & $3.41(.71)$ & $3.42(.77)$ & $3.44(.80)$ \\
\hline \multirow{3}{*}{$\begin{array}{l}\text { Part Three (B): } \\
\text { Professional } \\
\text { Learning } \\
\text { Preferences }\end{array}$} & Online Learning & $2.53(.99)$ & $2.72(.92)$ & $2.66(.96)$ & $2.67(.95)$ & $2.50(.94)$ & $2.52(.95)^{*}$ & $2.85(1.00)^{*}$ \\
\hline & $\begin{array}{l}\text { Face-to-Face Group } \\
\text { Learning }\end{array}$ & $3.48(.83)$ & $3.33(.89)$ & $3.33(.89)$ & $3.46(.83)^{*}$ & $3.27(.87)^{*}$ & $3.45(.84)$ & $3.35(.85)$ \\
\hline & One-on-One Learning & $3.60(1.11)^{*}$ & $3.13(1.17)^{*}$ & $2.90(1.15)^{*}$ & $3.39(1.15)$ & $3.29(1.20)$ & $3.45(1.15)$ & $3.20(1.11)$ \\
\hline
\end{tabular}

Note. ACAI = Approaches to Classroom Assessment Inventory; P/J = Primary/Junior; I/S = Intermediate/Senior.

$*$ indicates statistically significant results at $\mathrm{p}<.05$ confidence level 